\title{
Introducing Forensic Accounting Curiculum In Nigerian Universities: An Empirical Submission
}

\author{
James 0 Abiola Ph.D, FCA \\ Department of Accounting, \\ Management Sciences, Lagos State University, Ojo \\ Rilwan Ayinde Adisa \\ Department of Accounting, \\ Management Sciences, Lagos State University, Ojo
}

\begin{abstract}
Forensic accounting is seen as one of the most important careers that will gain increased future demand, yet most Nigerian universities do not offer it as a separate course especially at undergraduate level. This paper therefore examined the perceived benefits and obstacles of integrating forensic accounting into the accounting curriculum of Nigerian universities. A survey research method was adopted using questionnaire prepared on a 5point Likert scale and distributed among academics and students of tertiary institutions in Nigeria. The questionnaires were analysed using descriptive statistics. The findings revealed that the future demand and interest in forensic accounting education is expected to increase in spite of its attendant obstacles. It was also found that forensic accounting will promote responsible corporate governance, strengthen the credibility of financial reporting and make students more desirable in the market place. However, the major challenges of integrating forensic accounting into the accounting curriculum are the rigorous bureaucratic process in curriculum development for new programme and the lack of administrative interest and support. These results are useful to universities that are considering integrating forensic accounting into their accounting curriculum.
\end{abstract}

Keywords: forensic accounting, accounting curriculum, Nigerian universities, corporate governance, obstacle.

\section{INTRODUCTION}

The amount of frauds perpetrated by individuals and employees of corporate and public organizations and most recently the outburst and unwarranted financial reporting frauds and manipulations engaged in by Enron, WorldCom, HealthSouth, Tyco, Xerox, Parmalat, Satyam, SubPrime Mortgages, Olympus and others in the early 2000 taint the historical image of the accounting profession and therefore damage the confidence reposed by investors, policy makers and other stakeholders in the audited financial statement of organizations. Thus, as a bail out, forensic accounting - a scientific evaluation of cases of frauds in the event of legal or court demands - is inevitable. Ozili (2015) opined that forensic accounting is gaining significant research interests among academics. Particularly during the 2007-2009 global financial crises, the focus on FRF (Financial Reporting Fraud) prevention and detection became more important as policymakers, regulators, 
Abiola, J. O., \& Adisa, R. A. (2020) Introducing Forensic Accounting Curiculum In Nigerian Universities: An Empirical Submission. Archives of Business Research, 8(5). 19-32.

investors, and businesses worldwide became concerned about the existence and growth of FRF, as well as corporate malfeasance and misconduct. (Rezaee, Lo, Ha \& Seun, 2016).

Forensic accounting, in the words of Emeh and Obi (2013), is "the application of aspecialized knowledge and specific skills to stumble upon the evidence of economic transactions." The AICPA called forensic accounting as one of the seven hot, new, "sizzling" career areas in accounting (University of Pittsburgh, 2010).

Academicians and researchers alike are now advocating for the introduction of forensic accounting in higher institutions of learning as there are handful and quantum numbers of universities offering it either as a course on its own or as an integral part of their accounting programme. However, it is gathered, for instance, that University of Toronto offers a diploma in forensic accounting (Ramaswamy, 2007). On the other hand, some universities in India are considering adding forensic accounting course to their curriculum (Bhasin, 2013). A syllabus on Forensic Accounting and Fraud Examination from University of Pittsburgh shows that Forensic Accounting is being taught in the Katz Graduate School of Business (University of Pittsburgh, 2010). Thus, the demand for students with forensic accounting education was increasing, with the supply side of colleges and universities being strongly encouraged to respond by providing the necessary coursework (Seda, 2015).

In developing countries like Nigeria, forensic accounting education has not been given its due place in the academic environment. In consonance to the above assertion, Herbert, Onyilo, Ene and Tsegba (2017) stated that "Fraud examination and forensic accounting is not offered as a fullfledged undergraduate or postgraduate degree programme in Nigerian universities. And that at best, the two accountancy bodies (ANAN and ICAN) establishedcentres for forensic accounting education, as a platform for creating awareness of the growing importance of this newly specialized field for their members."

In view of the foregoing, the study aims to achieve the following:

1. Examine the necessity and relevance of integrating forensic accounting into the Accounting Curriculum at undergraduate and post graduate levels in Nigerian universities,

2. Explore the perceptions of students in the introduction of forensic accounting in Nigerian universities,

3. Evaluate empirically the challenges of introducing forensic accounting in Nigerian universities and also provide the likely solutions,

4. Design an appropriate syllabus or course contents for forensic accounting programmes in Nigerian universities.

Thus, the paper is divided into five sections. Section one dwells on the introduction of forensic accounting vis-à-vis fraud detection and prevention. Section two explores relevant literatures on the necessity as well as the attendant challenges for integrating forensic accounting in the accounting curriculum at undergraduate and post graduate level in Nigerian universities. The last three sections discuss the methodology, result and findings; and conclusions and recommendation. 


\section{Conceptual framework}

\section{LITERATURE REVIEW}

Forensic accounting is viewed as a practice of using technology and science to investigate and expose fraudulent activities and illegal practices involved in the areas of accounting, finance, management and criminology where fraud and illegal acts might take place, as well as valuation, risk assessment and dispute resolution (Rezaee, Lo, Ha, \& Suen, 2016).

In the words of Emeh and Obi (2013), forensic accounting is "the application of aspecialized knowledge and specific skills to stumble upon the evidence of economic transactions."As a discipline, forensic accounting encompasses financial expertise, fraud knowledge, and a sound knowledge and understanding of business reality and the working of the legal system.

Bologna and Lindquist as cited in Ozili (2015) and in the work of Omar and Jomitin as cited in Sorunke (2016) defined forensic and investigative accounting as "the application of financial skills and investigative mentality to resolve issues conducted within the context of rules of evidence. As a discipline, it encompasses financial expertise, fraud knowledge, and understanding of business reality and working of the legal system."

Forensic accounting is defined by Rezaee et al (2004) in the questionnaire distributed to selected academicians and accounting practitioners as "the practice of rigorous data collection and analysis in the areasof litigation support consulting, expert witnessing, and fraud examination."

Idris, Kehinde, Ajemunigbohun \& Gabriel (2012) defined forensic accounting as the investigative accounting done by forensic accounting consultants to solve problems usually in court. It deals with sensitive matters that involve complex financial matters, incomplete records, deception, lawyers, enforcement agencies and the legal system.

\section{A historical background of forensic accounting}

Despite the recent spotlight, forensic accounting is not new. Forensic accountants have been around for nearly 200 years. Its roots have been traced to 1824 in an accountant's advertising circular in Glasgow, Scotland. These special accountants gave testimony in court and in arbitration proceedings (Ramaswamy, 2007; Emeh and Obi, 2013). That notwithstanding, forensic accounting as a profession remained relatively unknown until the plethora of high-profile corporate scandals and stricter reporting and internal control regulations which brought to light its importance to the business world (Wallace as cited in Emeh and Obi, 2013).

Recent history indicates that Maurice E. Peloubet is credited with developing the term Forensic Accounting in his 1946 essay "Forensic Accounting". Although the term may not have been used before the 1940s, a strong argument can be made that the first high-profile forensic accountant was Frank J. Wilson, the man who spearheaded the campaign to convict Alphonse "Scarface" Capone of tax evasion in 1931 (Joshi as cited in Emeh and Obi, 2013).

Summarily, from the works of Ramaswamy (2007) and Emeh and Obi (2013), the followingare a few major milestones in forensic accounting:

- 1942: Maurice E. Peloubet published "Forensic Accounting: Its place in today's economy." 
Abiola, J. O., \& Adisa, R. A. (2020) Introducing Forensic Accounting Curiculum In Nigerian Universities: An Empirical Submission. Archives of Business Research, 8(5). 19-32.

- 1982: Francis C. Dykman wrote "Forensic Accounting: The Accountant as an Expert Witness."

- 1986: The AICPA issued Practice Aid \# 7, outlining six areas of litigation services - damages, antitrust analysis, accounting, valuation, general consulting and analyses.

- 1988: Association of Certified Fraud Examiners established.

- 1988: A new genre of detective novels where the forensic accountant was the star.

- 1992: The American College of Forensic Examiners was founded.

- 1997: The American Board of Forensic Accountants was founded.

- 2000: The Journal of Forensic Accounting, Auditing, Fraud and Taxation was founded.

- 2002: The Sarbanes-Oxley Act established the Public Companies Accounting Oversight Board (PCAOB) which was charged with developing auditing standards, conducting investigations and ensuring corporate compliance. As a result of the Sarbanes-Oxley Act, there has been continuing emphasis on forensic accounting.

\section{Teaching forensic accounting}

The need for training forensic accountants cannot be overemphasized sequel to the pervasiveness of fraud. The Association of Certified Fraud Examiners is actively encouraging universities to offer such courses by offering sample syllabi, videos and other material. The manners and approaches to teaching forensic accounting is gathered from the work of Ramaswamy (2007).

It must be noted that not all forensic accounting courses are taught in the same way but some of the approaches are presented as follow:

- A general course on all types of fraud perpetrated in all walks of life, including identity theft, telemarketing fraud, investment scams etc.

- A course specifically looking at fraud against organizations perpetrated by employees, vendors and customers

- A course specifically targeted at discovering financial statement fraud

- A fraud auditing and investigation course, looking at internal and external audit procedures

- A course dealing with gathering evidence of fraud, including testimonial, documentary, and surveillance evidence

- A course specifically targeted toward presenting evidence in court.

There is, of course, a lot of information overlap between these courses and their common focus is identifying and proving fraud. A sample syllabus for a general course in fraud would cover the following topics:

\section{Review of Empirical Studies}

Wallace as cited in Emeh and Obi (2013) asserted that forensic accounting has been termed the fastest growing area of accounting today. A study conducted by Kessler International (a forensic accounting and investigative firm) showed that there is a growing need for experienced forensic accountants (Ramaswamy, 2007).

Razaee, Crunbley and Elmore (2004) gather opinions of both academics and practitioners on the importance, relevance, and delivery of forensic accounting education. They found that the demand for and interest in forensic accounting is expected to continue to increase. They also revealed that 
both groups of respondent viewed forensic accounting education as being relevant and beneficial to accounting students, the business community, the accounting profession and programs.

In his study, Bhasin (2013) examined the necessary skills that will be required by would-be Forensic accountant. He found "deductive analysis" that is the ability to aim at financial contradictions that do not fit in the normal pattern of an assignment as the most important skill. This skill, he stated, is necessary and essential for forensic accountant to meet the objective of uncovering a potential financial fraud.

Al-Hadrami and Hidayat (2014) in their study on the obstacles of integrating forensic accounting in the accounting curriculum of Bahrain universities found that there is a future increased demand for forensic accounting. However, they discovered that obstacles related to academic matters (curriculum and faculty) are the most important obstacles that prevent the accounting departments in universities across Bahrain from offering a program or a course in forensic accounting.

Rezaee et al. (2016) posited that the existence and persistence of financial scandals, frauds and related financial crises have galvanized more interest in and demand for forensic accounting practices. Their findings revealed that the demand for and interest in forensic accounting practice is expected to continue to increase. They also posited that the results provide support for forensic accounting practices and education in China as the fastest-growing emerging market.

Sorunke (2016) investigated the challenges inhibiting Nigerian universities from integrating forensic accounting course into the accounting curriculum. He found that the demand and interest in forensic accounting in Nigeria is expected to increase. The study further revealed that the challenges of integrating forensic accounting into accounting curriculum is more of academic and administrative bottleneck.

\section{METHODOLOGY}

This study adopts survey questionnaire as it research methods following review of previous studies on forensic accounting education. The questionnaires were distributed among lecturers and students (undergraduate and post graduate) in Accounting and Finance Department in one federal university, one state university and a private university in Nigeria and students. The questionnaire is divided into two sections. The first section collects information about the demographic details of the respondents. While the second section entails likely questions related to forensic accounting.

The questions in the questionnaire are divided into three parts. The first part of questions collects information about accounting educators' views on the severity of the obstacles of integrating forensic accounting into accounting curriculum of universities in Nigeria. 5 Likert-scale type was adopted from being very severe ( 5 scale value) to not severe (1 scale value). The second part demands respondents' perception to the perceived benefits of forensic accounting education and practice using 5 Likert Scale of most important (5) to least important (1). The third part collects information about general overview of the respondents on forensic accounting. 
Abiola, J. O., \& Adisa, R. A. (2020) Introducing Forensic Accounting Curiculum In Nigerian Universities: An Empirical Submission. Archives of Business Research, 8(5). 19-32.

\section{DATA ANALYSIS AND FINDINGS}

This section presents the demographic profiles of the respondents (academics and students) as well as the analysis of the survey questionnaire distributed among academics and students on their perception on the obstacles and benefits of integrating forensic accounting in the accounting curriculum of Nigerian universities.

\section{Demographics of the respondents}

Table 1 shows the demographic details of the respondents (academicians). As seen in the table, majority of the respondents are male (66.7\%). Also, the table shows that more than $80 \%$ of the academicians surveyed holds a doctorate degree (Ph.Dholders); and half of them obtained a rank of senior lecturer (50\%), followed by the ranks of assistant lecturer (33.3\%) and associate professor (16.7\%) respectively. Additionally, 80 respondents (66.6\%) have over 15 years working experience.

Table 1: Demographic details of the respondents (Academicians)

\begin{tabular}{|l|c|c|}
\hline & FREQUENCY & PERCENT (\%) \\
\hline Gender & 80 & 66.7 \\
Female & $\underline{40}$ & $\underline{33.3}$ \\
Total & $\mathbf{1 2 0}$ & $\mathbf{1 0 0 . 0}$ \\
\hline Level of Education & 100 & 83.3 \\
\hline Ph.D & $\underline{20}$ & $\underline{16.7}$ \\
M.Sc & 120 & 100.0 \\
Total & & \\
\hline Academic Rank & 20 & 16.7 \\
Associate Professor & 60 & 50.0 \\
Senior Lecturer & $\underline{40}$ & $\underline{33.3}$ \\
Assistant Lecturer & $\mathbf{1 2 0}$ & $\mathbf{1 0 0 . 0}$ \\
Total & & 16.7 \\
\hline Work Experience & 20 & 16.7 \\
\hline Less than 5 years & 20 & $\underline{66.6}$ \\
6-10 years & $\underline{80}$ & $\mathbf{1 0 0 . 0}$ \\
Over 15 years & $\underline{\mathbf{1 2 0}}$ & 16.7 \\
Total & & 33.3 \\
\hline Professional Qualification & 20 & 16.7 \\
\hline ACA & 40 & $\underline{\mathbf{3 0 0 . 0}}$ \\
FCA & 20 & \\
ACCA & $\underline{\mathbf{1 2 0}}$ & \\
None & & \\
Total & & \\
\hline
\end{tabular}

Source: Field Survey (2018)

The analysis of the respondents shows that $33.3 \%$ of the respondents teaches forensic accounting while the remaining 66.7\% do not teach it (see Appendix: Table 3, Panel A). This result is in agreement with Al-Hadrami and Hidayat (2014) who found that $29.4 \%$ of educators in Bahrain are not familiar with forensic accounting. This therefore calls for more sensitization and awareness about the need for forensic accounting education in Nigerian universities. 
Table 2: Demographic details of the respondents (Students)

\begin{tabular}{|l|c|c|}
\hline & FREQUENCY & PERCENT (\%) \\
\hline Gender & 71 & 47.3 \\
Female & $\underline{79}$ & $\underline{52.7}$ \\
Total & $\mathbf{1 5 0}$ & $\mathbf{1 0 0 . 0}$ \\
\hline Educational Qualification & & 62.0 \\
Undergraduate & 93 & 2.0 \\
OND & 3 & 18.0 \\
B.Sc & 27 & $\underline{18.0}$ \\
M.Sc & $\underline{27}$ & $\mathbf{1 0 0 . 0}$ \\
Total & $\mathbf{1 5 0}$ & 8.8 \\
\hline Professional Qualification & 13 & 2.0 \\
AATWA & 3 & 2.0 \\
ACA & 3 & $\underline{87.1}$ \\
ACCA & $\underline{\mathbf{1 2 8}}$ & $\underline{\mathbf{1 0 0 . 0}}$ \\
None & $\underline{\mathbf{3}}$ & \\
Sub-Total & $\underline{\mathbf{5 0}}$ & \\
Missing & & \\
Total & & \\
\hline
\end{tabular}

Source: Field Survey (2018)

Table 2 above shows the demographic details of the respondents (students). As indicated in the table, $71(47.3 \%)$ are male while the remaining $79(52.7 \%)$ are female respondents. The table also indicates that majority $(62.0 \%)$ of the responded students are undergraduate in Nigerian universities while others with $2 \%, 18 \%$ and $18 \%$ responding rates are holders of Ordinary National Diploma, Bachelor of Science degree and Masters degree respectively. In terms of professional qualification, majority of the respondents (87.1\%) do not possess any. Few who are qualified professionally have AATWA (8.8\%), ACA (2\%) and ACCA (2\%).

\section{Benefits of Forensic Accounting Education}

The respondents (both the academicians and students) were asked to rank the importance of perceived benefits of forensic accounting education on a 5-point Likert scale with "5" representing "Most important" and "1" indicating "least important".

As shown in Table 3 below, the academiciansconsidered the following benefits as being important (mean response of equal/higher than 4.0): (1) Promoting responsible corporate governance (2) Strengthening the credibility of financial reporting (3) Making students more desirable in the market place (4) Satisfying society's demand for forensic accounting education and practice (5) Demanding for individuals possessing forensic accounting education and skills is increasing.

The responded students, on the other hand, considered the following in the order of presentation as important benefits of forensic accounting education (mean response of equal/higher than 4.0): (1) Promoting responsible corporate governance (2) Strengthening the credibility of financial reporting (3) Satisfying society's demand for forensic accounting education and practice.

Both sampled respondents perceived "preparation of students to engage in fraud examination" as the least important benefits of forensic accounting education. 
Abiola, J. O., \& Adisa, R. A. (2020) Introducing Forensic Accounting Curiculum In Nigerian Universities: An Empirical Submission. Archives of Business Research, 8(5). 19-32.

Table 3: Perceived benefits of forensic accounting education - Academicians and students' opinion

\begin{tabular}{|c|c|c|c|c|}
\hline \multirow{2}{*}{ Benefits } & \multicolumn{2}{|c|}{ Academicians } & \multicolumn{2}{c|}{ Students } \\
\cline { 2 - 5 } & $\begin{array}{c}\text { Mean } \\
\text { Response }\end{array}$ & $\begin{array}{c}\text { Standard } \\
\text { Deviation }\end{array}$ & $\begin{array}{c}\text { Mean } \\
\text { Response }\end{array}$ & $\begin{array}{c}\text { Standard } \\
\text { Deviation }\end{array}$ \\
\hline $\begin{array}{c}\text { Satisfy society's demand for forensic accounting } \\
\text { education and practice }\end{array}$ & 4.00 & 0.580 & 4.14 & 1.123 \\
\hline Strengthen the credibility of financial reporting. & 4.50 & 0.502 & 4.25 & 1.237 \\
\hline Promote responsible corporate governance. & 4.67 & 0.473 & 4.25 & 1.198 \\
\hline Make students more desirable in the marketplace. & 4.33 & 0.473 & 3.47 & 1.441 \\
\hline $\begin{array}{c}\text { Demand for individuals possessing forensic accounting } \\
\text { education and skills is increasing. }\end{array}$ & 4.00 & 0.580 & 3.73 & 1.230 \\
\hline Prepare students to engage in fraud examination. & 3.50 & 1.264 & 2.97 & 1.689 \\
\hline $\begin{array}{c}\text { Prepare students to engage in litigation support } \\
\text { consulting. }\end{array}$ & 4.00 & 0.580 & 3.44 & 1.454 \\
\hline Prepare students to engage in expert witnessing. & 3.83 & 0.901 & 3.81 & 1.195 \\
\hline
\end{tabular}

Source: Field Survey (2018)

\section{Obstacles of integrating forensic accounting into accounting curriculum}

Table 4: Perceived Obstacles in the integration of forensic accounting into the accounting curriculum - Academicians' opinion

\begin{tabular}{|c|c|c|c|}
\hline Obstacles* $^{*}$ & $\begin{array}{c}\text { Mean } \\
\text { Responses }\end{array}$ & Median & $\begin{array}{l}\text { Standard } \\
\text { Deviation }\end{array}$ \\
\hline Limited room for additional courses in the accounting curriculum & 2.33 & 2.00 & 1.252 \\
\hline $\begin{array}{l}\text { Rigorous bureaucratic process in curriculum development for new } \\
\text { programme }\end{array}$ & 3.17 & 3.50 & 0.901 \\
\hline No qualified lecturers to teach forensic accounting topics & 2.67 & 2.00 & 1.380 \\
\hline Not of significant importance to be included in the curriculum & 2.00 & 1.00 & 1.534 \\
\hline Lack of administrative interest and support & 3.17 & 4.00 & 1.218 \\
\hline Scarcity of instructional materials & 2.17 & 2.00 & 0.901 \\
\hline Absence of job opportunities & 2.17 & 2.00 & 1.072 \\
\hline No student interest & 2.67 & 2.50 & 1.497 \\
\hline
\end{tabular}

*Other obstacles being reported are no slack in the curriculum and many other required course

Table 4 above shows the academicians' opinions on the perceived obstacles in the integration of forensic accounting into the accounting curriculum. The result (mean score of 3.17) indicates that "rigorous bureaucratic process in curriculum development for new programme" and "lack of administrative interest and support" as the most severe obstacles perceived in integrating forensic accounting in the accounting curriculum of Nigerian universities. This result agrees with the findings of Al-Hadrami and Hidayat (2014) who found that in Bahrain, the greatest academic obstacle is that there is no space for additional course in the accounting curriculum.

\section{CONCLUSIONS}

The quantum of frauds perpetrated by individuals and employees of corporate and public organizations and most recently the outburst and unwarranted financial reporting frauds and manipulations engaged in by Enron, WorldCom and others in the early 2000 disparage the historical image of the accounting profession and therefore damage the confidence reposed by 
investors, policy makers and other stakeholders in the audited financial statement of organizations. Forensic accounting was therefore considered as a bail out. Forensic accounting is seen as one of the most important careers that will gain increased future demand, yet most Nigerian universities do not offer it as a separate course especially at undergraduate level. Academics and researchers alike are now advocating for the introduction of forensic accounting in higher institutions of learning.

It was also found that forensic accounting will promote responsible corporate governance, strengthen the credibility of financial reporting and make students more desirable in the market place. It was found that the most severe obstacles of integrating forensic accounting into the accounting curriculum are the rigorous bureaucratic process in curriculum development for new programme and the lack of administrative interest and support. It is therefore concluded that the results of this study would assist institutions who are planning to integrate forensic accounting into their curriculum.

\section{References}

Al-Hadrami, A. \& Hidayat, S. (2014). Obstacles of integrating Forensic Accounting in the Accounting Curriculum: The Bahrain. Proceedings of Eurasia Business Research Conference, 16 - 18 June 2014, Nippon Hotel, Istanbul, Turkey.

Amake, C. C. \& Ikhatua, O. J. (2016). Forensic accounting and fraud detection in Nigerian public sector. Igbinedion University Journal of Accounting, 2, 148-173.

Anichebe, A.S. \& Manukaji, I. J. (2016). Relevance of forensic auditing as an investigative tool in curbing financial crimes in public sectors organization. Journal of Accounting and Financial Management, 2(3), 40-49.

Bhasim, M. (2013). An empirical investigation of the relevant skills of forensic accountants: Experience of a developing economy. European Journal of Accounting, Auditing and Finance Research,1(2), 11-52.

Emeh, Y. \& Obi, J. O. (2013). An empirical analysis of forensic accounting and financial fraud in Nigeria. African Journal of Social Sciences,3(4), 112-121.

Enofe, A. O., Julius, O. M. \& Ogbeide, O. L. (2015). The role of forensic accounting in combating financial crimes. Research Journal of Finance and Accounting,6(18), 191-199.

Herbert, W. E., Onyilo, F., Ene, E. E. \& Tsegba, I. N. (2017). Fraud and Forensic Accounting Education: Prospects and challenges in Nigeria. International Journal of Business and Management,12(7), 146-161. Doi:

10.5539/ijbm.v12n7p146

Idris, A. A., Kehinde, J. S., Ajemunigbohun, S. S. A. \& Gabriel, J. M. O. (2012). The nature, techniques and prevention of creative accounting: Empirical evidence from Nigeria. Canadian Journal of Accounting and Finance, 1(1), 26-31.

Ozili, P. K. (2015). Forensic accounting and fraud: A review of literature and policy implications. International Journal of Accounting and Economics Studies,3(1), 63-68.

Ramaswamy, V. (2007). New frontiers: Training Forensic Accountants within the accounting program. Journal of College Teaching and Learning,4(9), 31-38.

Rezaee, Z., Crumbley, D. L. \& Elmore, R. C. (2004). Forensic accounting education: A survey of academicians and practitioners.

Rezaee, Z., Lo, D., Ha, M. \& Suen, A. (2016). Forensic accounting education and practice: insights from China. Journal of Forensic and Investigative Accounting,8(1), 106-119.

Seda, M. \& Kramer, B. K. P. (2015). A comparison of U.S Forensic Accounting Programs with the National Institute of Justice Funded Model Curriculum. Journal of Forensic and Investigative Accounting,7(2), 144-177. 
Abiola, J. O., \& Adisa, R. A. (2020) Introducing Forensic Accounting Curiculum In Nigerian Universities: An Empirical Submission. Archives of Business Research, 8(5). 19-32.

Sorunke, 0. A. (2016). Integrating Forensic Accounting into the Accounting Curriculum in Nigeria Universities: Challenges and remedies. International Journal of AcademicResearch in Progressive Education and Development,5(1), 59-64. Doi: 10.6007/IJARPED/v5-i1/2062

University of Pittsburgh (2010). Course Calendar (Fall 2010) on Forensic Accounting and Fraud Examination (BACC 2251) of Katz Graduate School of Business, University of Pittsburgh. Retrieved on 11/12/17 from http://inet.katz.piit.edu/Pinstripes/BGP\%2520MBA\%252011\%2520-\%2520Syllabus\%2520$\% 2520$ BACC $\% 25202251 \% 2520$ -

\%2520Forensic2520Acctg\%2520and\%2520Fraud\%2520Examination\%2520(Hoffman).docx

\section{APPENDIX}

Table 1: Forensic Accounting And Fraud Examination

\begin{tabular}{|ll|}
\hline \multicolumn{1}{|c|}{ COURSE CONTENT } \\
\hline 1. & Introduction and course overview - the nature of fraud \\
\hline 2. & Why people commit fraud \\
\hline 3. & An overview of Forensic Accounting and fighting fraud \\
\hline 4. & Fraud prevention and recognizing fraud symptoms \\
\hline 5. & Proactive detection of fraud \\
\hline 6. & Investigating theft acts and investigating concealment \\
\hline 7. & Investigating conversion \\
\hline 8. & Financial stamen fraud - overview \\
\hline 9. & Revenue fraud \\
\hline 10. & Planning audits to detect fraud \\
\hline 11. & Inventory fraud \\
\hline 12. & Liability, asset and inadequate disclosure frauds \\
\hline 13. & Other frauds against organizations \\
\hline 14. & Consumer fraud \\
\hline 15. & Bankruptcy, divorce and tax fraud \\
\hline 16. & Regulating the detection of financial statement fraud and course wrap-up \\
\hline
\end{tabular}

Source: Course Calendar (Fall 2010) on Forensic Accounting and Fraud Examination (BACC 2251) of Katz Graduate School of Business, University of Pittsburgh. Retrieved on 11/12/17 from http://inet.katz.piit.edu/Pinstripes/BGP\%2520MBA\%252011\%2520-\%2520Syllabus\%2520\%2520BACC\%25202251\%2520-

\%2520Forensic2520Acctg\%2520and\%2520Fraud\%2520Examination\%2520(Hoffman).docx 
Table 2: Forensic Accounting Course Description, Objectives, And Assignments

\begin{tabular}{|c|c|c|c|c|c|}
\hline Course Description & Percent & Course Objectives & Percent & Assignments & Percent \\
\hline 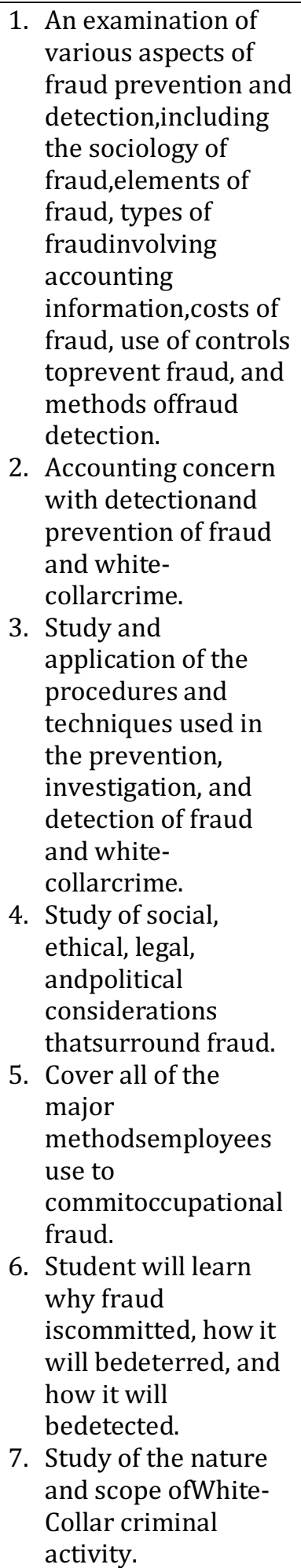 & 54 & $\begin{array}{l}\text { 1. Provide education } \\
\text { onpervasiveness of } \\
\text { and the causes offraud } \\
\text { and white- collar } \\
\text { crime. } \\
\text { 2. Explore methods of } \\
\text { frauddetection, } \\
\text { investigation, } \\
\text { andprevention. } \\
\text { 3. Obtain insight on fraud } \\
\text { prevention and } \\
\text { identifying weaknesses } \\
\text { in internal control } \\
\text { systems. } \\
\text { 4. Acquire a broad } \\
\text { overview of thenature } \\
\text { and magnitude of } \\
\text { theproblem of } \\
\text { economic fraud. } \\
\text { 5. Provide students an } \\
\text { opportunity togain } \\
\text { experience in } \\
\text { investigative(forensic) } \\
\text { accounting. } \\
\text { 6. Increase fraud } \\
\text { awareness. } \\
\text { 7. Learn aspects of fraud } \\
\text { detection. } \\
\text { 8. Understand the role of } \\
\text { accountant in } \\
\text { prevention, detection, } \\
\text { andinvestigation of } \\
\text { fraud. } \\
\text { 9ctivity } \\
\text { perpetrators offraud. } \\
\text { 10. The warning } \\
\text { The motivation for } \\
\text { and fraudulent } \\
\text { and }\end{array}$ & $\begin{array}{l}5 \\
5 \\
5\end{array}$ & $\begin{array}{l}\text { 1. Individual } \\
\text { writtenassignments } \\
\text { 2. Research projects } \\
\text { 3. Academic } \\
\text { researchjournal } \\
\text { readings } \\
\text { 4. Group projects } \\
\text { 5. Internet } \\
\text { readings,practitioner } \\
\text { journalreadings } \\
\text { 6. Text book readings } \\
\text { 7. Discussion and } \\
\text { oralpresentations } \\
\text { 8. Interview paper }\end{array}$ & $\begin{array}{l}100 \\
100 \\
95 \\
90 \\
86 \\
\\
57 \\
43 \\
38\end{array}$ \\
\hline Total & 100 & & 100 & & \\
\hline
\end{tabular}

Source: Rezaee, Z., Crumbley, D. L. \& Elmore, R. C. (2004). Forensic accounting education: A survey of academicians and practitioners. 
Abiola, J. O., \& Adisa, R. A. (2020) Introducing Forensic Accounting Curiculum In Nigerian Universities: An Empirical Submission. Archives of Business Research, 8(5). 19-32.

\section{Table 3}

Panel A: Demographic Data of Academicians

\begin{tabular}{|c|c|c|c|c|c|}
\hline \multicolumn{2}{|c|}{} & Frequency & Percent & Valid Percent & $\begin{array}{c}\text { Cumulative } \\
\text { Percent }\end{array}$ \\
\hline \multirow{3}{*}{ Valid } & Male & 80 & 66.7 & 66.7 & 66.7 \\
\cline { 2 - 6 } & Female & 40 & 33.3 & 33.3 & 100.0 \\
\cline { 2 - 6 } & Total & 120 & 100.0 & 100.0 & \\
\hline
\end{tabular}

\begin{tabular}{|c|c|c|c|c|c|}
\hline \multicolumn{6}{|c|}{ Level of Education } \\
\hline \multirow{2}{*}{} & Frequency & Percent & Valid Percent & $\begin{array}{c}\text { Cumulative } \\
\text { Percent }\end{array}$ \\
\hline \multirow{3}{*}{ Valid } & Ph.D & 100 & 83.3 & 83.3 & 83.3 \\
\cline { 2 - 6 } & M.Sc & 20 & 16.7 & 16.7 & 100.0 \\
\cline { 2 - 6 } & Total & 120 & 100.0 & 100.0 & \\
\hline
\end{tabular}

\begin{tabular}{|c|c|c|c|c|c|}
\hline \multicolumn{7}{|c|}{ Academic Rank } \\
\hline \multirow{3}{*}{} & Frequency & Percent & Valid Percent & $\begin{array}{c}\text { Cumulative } \\
\text { Percent }\end{array}$ \\
\hline \multirow{3}{*}{ Valid } & Associate Professor & 20 & 16.7 & 16.7 & 16.7 \\
\cline { 2 - 6 } & Senior Lecturer & 60 & 50.0 & 50.0 & 66.7 \\
\cline { 2 - 6 } & Assistant Lecturer & 40 & 33.3 & 33.3 & 100.0 \\
\cline { 2 - 6 } & Total & 120 & 100.0 & 100.0 & \\
\hline
\end{tabular}

\begin{tabular}{|c|c|c|c|c|c|}
\hline \multicolumn{2}{|c|}{} & Work Experience \\
\hline \multirow{7}{*}{} & Frequency & Percent & Valid Percent & $\begin{array}{c}\text { Cumulative } \\
\text { Percent }\end{array}$ \\
\hline \multirow{4}{*}{ Valid } & Less than 5 years & 20 & 16.7 & 16.7 & 16.7 \\
\cline { 2 - 6 } & 6-10 Years & 20 & 16.7 & 16.7 & 33.3 \\
\cline { 2 - 6 } & Over 15 years & 80 & 66.7 & 66.7 & 100.0 \\
\cline { 2 - 6 } & Total & 120 & 100.0 & 100.0 & \\
\hline
\end{tabular}

\begin{tabular}{|c|c|c|c|c|c|}
\hline \multicolumn{2}{|c|}{ Professional Qualification } \\
\hline \multirow{2}{*}{} & Frequency & Percent & Valid Percent & Cumulative Percent \\
\hline \multirow{7}{*}{ Valid } & ACA & 20 & 16.7 & 16.7 & 16.7 \\
\cline { 2 - 6 } & FCA & 40 & 33.3 & 33.3 & 50.0 \\
\cline { 2 - 6 } & ACCA & 20 & 16.7 & 16.7 & 66.7 \\
\cline { 2 - 6 } & None & 40 & 33.3 & 33.3 & 100.0 \\
\cline { 2 - 6 } & Total & 120 & 100.0 & 100.0 & \\
\hline
\end{tabular}




\begin{tabular}{|c|c|c|c|c|c|}
\hline \multicolumn{6}{|c|}{ Do you teach forensic accounting? } \\
\hline \multirow{2}{*}{} & Frequency & Percent & Valid Percent & $\begin{array}{c}\text { Cumulative } \\
\text { Percent }\end{array}$ \\
\hline \multirow{3}{*}{ Valid } & Yes & 40 & 33.3 & 33.3 & 33.3 \\
\cline { 2 - 6 } & No & 80 & 66.7 & 66.7 & 100.0 \\
\cline { 2 - 6 } & Total & 120 & 100.0 & 100.0 & \\
\hline
\end{tabular}

\begin{tabular}{|c|c|c|c|c|c|}
\hline \multicolumn{6}{|c|}{$\begin{array}{l}\text { What do you expect of the future demand and interest in forensic accounting } \\
\text { education? }\end{array}$} \\
\hline & & Frequency & Percent & Valid Percent & $\begin{array}{l}\text { Cumulative } \\
\text { Percent }\end{array}$ \\
\hline Valid & Increase & 120 & 100.0 & 100.0 & 100.0 \\
\hline
\end{tabular}

\begin{tabular}{|c|c|c|c|c|c|}
\hline \multicolumn{5}{|c|}{ At what level do you think a forensic accounting course should be offered? } \\
\hline \multicolumn{2}{|c|}{} & Frequency & Percent & Valid Percent & $\begin{array}{c}\text { Cumulative } \\
\text { Percent }\end{array}$ \\
\hline Valid & $\begin{array}{c}\text { Both undergraduate and } \\
\text { post-graduate }\end{array}$ & 120 & 100.0 & 100.0 & 100.0 \\
\hline
\end{tabular}

\section{If Forensic accounting is to be taught at undergraduate level, what level do you suggest?}

\begin{tabular}{|c|c|c|c|c|c|}
\hline \multicolumn{2}{|c|}{} & Frequency & Percent & Valid Percent & $\begin{array}{c}\text { Cumulative } \\
\text { Percent }\end{array}$ \\
\hline \multirow{3}{*}{ Valid } & 300 Level & 80 & 66.7 & 66.7 & 66.7 \\
\cline { 2 - 6 } & 400 Level & 40 & 33.3 & 33.3 & 100.0 \\
\cline { 2 - 6 } & Total & 120 & 100.0 & 100.0 & \\
\hline
\end{tabular}

\begin{tabular}{|c|c|c|c|c|c|}
\hline \multicolumn{6}{|c|}{ Will students be interested in learning forensic accounting? } \\
\hline & Frequency & Percent & Valid Percent & Cumulative Percent \\
\hline Valid & Yes & 120 & 100.0 & 100.0 & 100.0 \\
\hline
\end{tabular}

Panel B: Demographic Data of Students

\begin{tabular}{|c|c|c|c|c|c|}
\hline \multicolumn{2}{|c|}{} & Frequency & Percent & Valid Percent & $\begin{array}{c}\text { Cumulative } \\
\text { Percent }\end{array}$ \\
\hline \multirow{3}{*}{ Valid } & Male & 71 & 47.3 & 47.3 & 47.3 \\
\cline { 2 - 6 } & Female & 79 & 52.7 & 52.7 & 100.0 \\
\cline { 2 - 6 } & Total & 150 & 100.0 & 100.0 & \\
\hline
\end{tabular}


Abiola, J. O., \& Adisa, R. A. (2020) Introducing Forensic Accounting Curiculum In Nigerian Universities: An Empirical Submission. Archives of Business Research, 8(5). 19-32.

\begin{tabular}{|c|c|c|c|c|c|}
\hline \multicolumn{2}{|c|}{} & Educational Qualification & Cumulative \\
\hline \multirow{2}{*}{} & Frequency & Percent & Valid Percent & $\begin{array}{c}\text { Percent } \\
\text { Pent }\end{array}$ \\
\cline { 2 - 6 } & Undergraduate & 93 & 62.0 & 62.0 & 62.0 \\
\cline { 2 - 6 } Valid & OND & 3 & 2.0 & 2.0 & 64.0 \\
\cline { 2 - 6 } & B.Sc & 27 & 18.0 & 18.0 & 82.0 \\
\cline { 2 - 6 } & M.Sc & 27 & 18.0 & 18.0 & 100.0 \\
\cline { 2 - 6 } & Total & 150 & 100.0 & 100.0 & \\
\hline
\end{tabular}

\begin{tabular}{|c|c|c|c|c|c|}
\hline \multicolumn{6}{|c|}{ Professional Qualification } \\
\hline & & Frequency & Percent & Valid Percent & $\begin{array}{c}\text { Cumulative } \\
\text { Percent }\end{array}$ \\
\hline \multirow{5}{*}{ Valid } & AATWA & 13 & 8.7 & 8.8 & 8.8 \\
\hline & ACA & 3 & 2.0 & 2.0 & 10.9 \\
\hline & ACCA & 3 & 2.0 & 2.0 & 12.9 \\
\hline & None & 128 & 85.3 & 87.1 & 100.0 \\
\hline & Total & 147 & 98.0 & 100.0 & \\
\hline Missing & System & 3 & 2.0 & & \\
\hline \multicolumn{2}{|c|}{ Total } & 150 & 100.0 & & \\
\hline
\end{tabular}

What do you expect of the future demand and interest in forensic accounting education?

\begin{tabular}{|c|c|c|c|c|c|}
\hline \multicolumn{2}{|c|}{} & Frequency & Percent & Valid Percent & $\begin{array}{c}\text { Cumulative } \\
\text { Percent }\end{array}$ \\
\hline \multirow{3}{*}{ Valid } & Increase & 144 & 96.0 & 96.0 & 96.0 \\
\cline { 2 - 6 } & Remain the same & 3 & 2.0 & 2.0 & 98.0 \\
\cline { 2 - 6 } & Unsure & 3 & 2.0 & 2.0 & 100.0 \\
\cline { 2 - 6 } & Total & 150 & 100.0 & 100.0 & \\
\hline
\end{tabular}

\begin{tabular}{|c|c|c|c|c|c|}
\hline \multicolumn{6}{|c|}{ At what level do you think a forensic accounting course should be offered? } \\
\hline \multirow{2}{*}{} & Frequency & Percent & Valid Percent & $\begin{array}{c}\text { Cumulative } \\
\text { Percent }\end{array}$ \\
\hline \multirow{4}{*}{ Valid } & Undergaduate only & 12 & 8.0 & 8.0 & 8.0 \\
\cline { 2 - 6 } & Post-graduate only & 9 & 6.0 & 6.0 & 14.0 \\
\cline { 2 - 6 } & $\begin{array}{c}\text { Both undergraduate and } \\
\text { post-graduate }\end{array}$ & 129 & 86.0 & 86.0 & 100.0 \\
\cline { 2 - 6 } & Total & 150 & 100.0 & 100.0 & \\
\hline
\end{tabular}

\begin{tabular}{|c|c|c|c|c|c|}
\hline & & Frequency & Percent & Valid Percent & $\begin{array}{c}\text { Cumulative } \\
\text { Percent }\end{array}$ \\
\hline \multirow{5}{*}{ Valid } & 100 Level & 16 & 10.7 & 10.7 & 10.7 \\
\hline & 200 Level & 49 & 32.7 & 32.7 & 43.3 \\
\hline & 300 Level & 51 & 34.0 & 34.0 & 77.3 \\
\hline & 400 Level & 34 & 22.7 & 22.7 & 100.0 \\
\hline & Total & 150 & 100.0 & 100.0 & \\
\hline
\end{tabular}

